\title{
FACTORS AFFECTING PROJECT MANAGEMENT IN THE PUBLIC SECTOR
}

\author{
Ivana NEKVAPILOVA, Jaromir PITAS \\ University of Defence, Brno, Czech Republic \\ ivana.nekvapilova@unob.cz, jaromir.pitas@unob.cz
}

\begin{abstract}
Abiding by the principles and rules of project management in the public administration environment provides project managers with a range of pitfalls that can influence the success of the project. This fact has been proved by a number of analysed projects. The managers themselves claim that the most challenging problem from the perspective of project management and assessment of the project success is the field of leadership (the leading of the project team by a project manager). The authors of this article have therefore identified the most important factors for assessing the success of the project management of a team by a manager at various stages of the lifecycle of a project. Furthermore, both the direct and indirect impact of not respecting these factors in achieving the project objectives and in creation of job satisfaction within the project team have been presented in compliance with the data analysis of completed projects in the public sector and the authors' own experience in dealing with projects in the public sector. The article offers approaches to mitigate some negative aspects regarding the principles and rules of project management according to recognized international standards. Although the article is primarily intended for project managers in the public administration environment, it can also provide some inspiration for fresh approaches to the field of leadership for project managers in the private sector. This article was written as a part of the project Development of Social Skills of a Soldier (LEADER_DZRO_K104), funded by institutional support, which is intended for the development of research organizations in the Ministry of Defence (DZRO K-104) funded from.
\end{abstract}

\section{Keywords: project life cycle, project team, project manager, leadership}

\section{Introduction}

It seems quite natural that every sponsor/beneficiary and project manager is interested in ensuring that their project is successful. However, relatively little attention is paid to project evaluation within large organizations of over 500 employees. This surprising fact arises from surveys carried out by the consulting company PM CONSULTING Ltd. in cooperation with the Association for Project Management and the National Association of Project Managers in 2012 and 2015. In 2015, only slightly more than half $(59 \%)$ of the 141 respondents indicated that their organizations formally evaluate the impacts and benefits of a project after completing its implementation. The project's impacts are not evaluated by $34 \%$ organizations and $7 \%$ of respondents did not know whether the impacts are evaluated at all. $16 \%$ of those questioned for the survey were project managers working in the public sector and in services.

These findings lead to speculation as to what extent the organization and the managers themselves create the conditions for sharing experiences and strengthening 
the prospect of learning by doing, in order to achieve higher quality of project outcomes, to mitigate risks complicating the successful management of projects, and consequently to raise the willingness of experts to regularly work in project teams.

Both surveys unambiguously linked the biggest problems threatening the success of projects in the Czech Republic with human resources. Primarily, in this area respondents often referred to the insufficient competence of the project team members, or a lack of capacity and congestion of team members. If we think about the basis of further identified problem areas, which are mostly ambiguous assignment or a poorly defined scope of the project $(55 \%)$, complications caused by changes during the project implementation (34\%), a lack of communication in project management (19\%), and overall culture in the organization $(31 \%)$, it is obvious that the most important factor affecting the success of a project is people management. $[7,8]$

The authors believe that the defined problem areas are even further exaggerated in the case of long-term projects, which are mostly carried out in a public administration. The aim of the paper is therefore to identify the most important factors influencing successful project management by a team manager at the various stages of the project lifecycle. Furthermore, based on data analysis of completed projects in the public sector and the authors' experience in dealing with projects in the public sector, the aim is to show the direct and indirect impacts of not respecting these factors in achieving the project objectives and the creation of job satisfaction in the project team. The article offers some approaches to mitigate some negative impacts of respecting the principles and rules of project management according to recognized international standards.

\section{Factors of successfulness of the project management team in relation to the project life cycle}

Experts recommend finding an answer to the question of whether the project team was successful or not, in the selected concept of regulation. Was a managerial approach applied or was the attention of the project team management paid instead to meeting the project objectives? Even if, in practice, both approaches are interconnected, it is necessary to be aware of the fact that each of these generates a different kind of behaviour in all team members and puts different demands on the project manager. Neither of these approaches stands up in the long term. Leadership without management may be changed in an adventurous, but apparently unsustainable and self-serving "game with change". "Management without a clear vision, arising on the basis of the knowledge of environment and realistic but still inspiring directing will be just a mindless completing tasks or achievement of objectives whose achievement might never happen". [10]

What are managers focused on while managing project teams? "To achieve results, management performance of team members, and ensuring stability" [10]. By contrast, a leader's attention is focused on understanding of the conditions, setting direction, empowerment of the people" [10]. It is advisable to prioritize the team project management to managing in projects and environments with high levels of instability in the external environment in long-term projects, where managers must cope with declining motivation of project team members as well as with other adverse effects for the project.

What factors contribute to the successful management of project teams? Logically, there is their division into external and internal. The external factors can be classified as the possibility of a manager to choose the appropriate project team members and functional cooperation 
of subjects participating in the project. Internal factors, which will be the subject of detailed analysis, are associated with the executive abilities of a leader to lead people and the ability of team members to be led. They are usually divided into professional skills, methodological and procedural skills, social and communication skills, the ability of integration and self-management. [1] The authors consider it useful to deal with these factors in detail, especially depending on the stage of the project.

\subsection{General life cycle of a project and a phase of forming the project team}

Project management theory states that each project must go through its life cycle, in which the project is managed by a project manager. Analogously, the project team will be at different stages of development. For each stage it will be necessary to choose the appropriate methods and techniques of management.

To identify factors influencing the success of the project team management the authors of the article have deliberately chosen a generic life cycle, which is defined by the implemented processes. They are fully aware of the fact that in the scientific literature a number of models of project life cycle are defined, but depending on different criteria (according to areas of human activities). The general project life cycle includes four main phases: Initiation, Planning, Realization, Termination (see Figure 1). [2, 4, 5, 6]

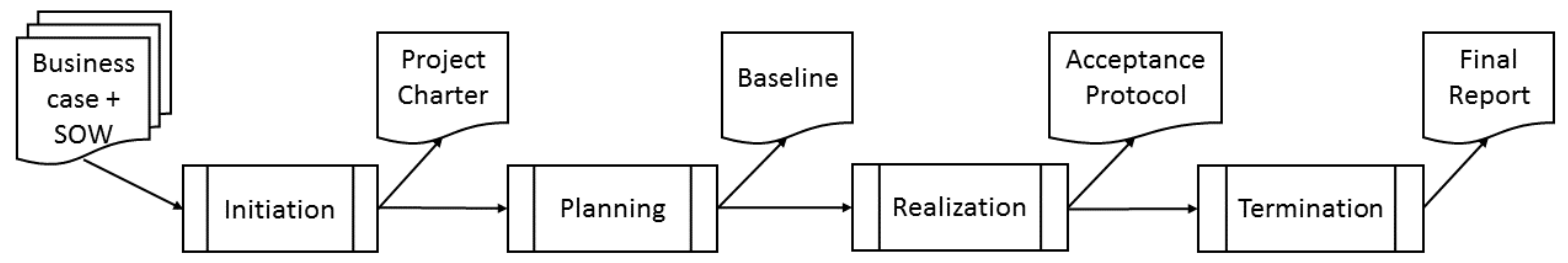

Figure 1: Project life cycle

However, depending on the project duration, certain partial changes can occur. The conceptual phases of projects carried out within a year (short-term) are not usually divided into sub-stages. In contrast, the implementation phase of projects longer than one year (long-term) is generally divided into several stages, when the output of one project stage becomes the input of the next stage. One of the principles of project management in relation to the stage management of a project implementation states that each partial stage of a project stage should be properly evaluated in order for the next phase of the project to be launched. The reason is the generated output of a sub-stage, which becomes the input to the next stage. The actual form of the output creation influences the next stage in terms of implementation schedule, implementation of necessary actions to achieve the desired output, costs involved and the resources to respect consistently the project objectives. This means that all the partial phases the project goes through represent its internal life cycle (see Figure 2).

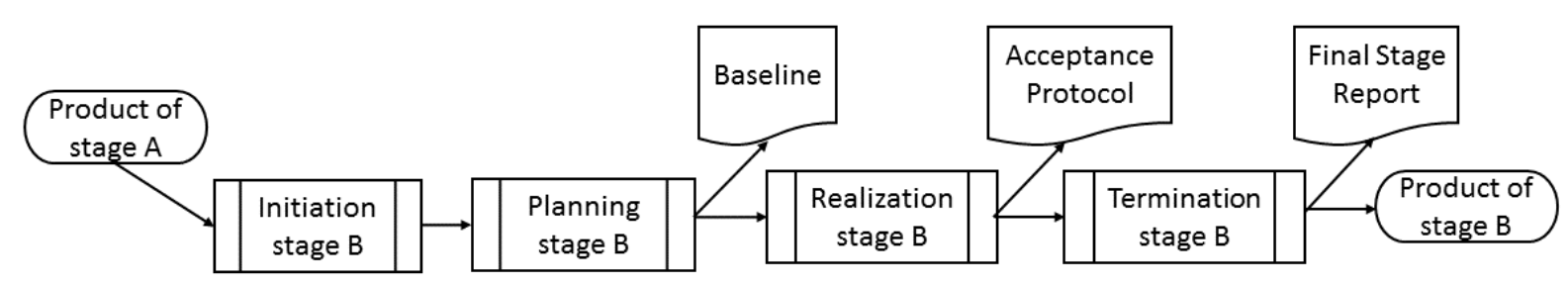

Figure 2: Internal life cycle of a partial project implementation

The starting point (the condition) to launch a project's lifecycle is a formulation and approval of the Business Case and
Statement of Work (SOW), which define the product scope (the scope of the final product of the project) $[2,6,9]$. The initial 
phase of the project life cycle is also related to a moment of starting to assemble the project team. A precondition of a successful beginning is a very timely appointment of a project manager, at the latest at the moment of the Business Case approval [5]. The project manager, in cooperation with the project sponsor/project manager (portfolio) and line managers of an organization, chooses (Forming) project personnel (so called the core project team). At the beginning of the project initiation phase the project team is built.

Subsequently, whilst still in the initial phase of the project, the project manager convenes an inaugural workshop, in which:

- the project team is acquainted with the project assignment (content and Business case, Statement of Work); established (communication, reporting, project meetings, etc.)

- individual roles and responsibilities of project team members are defined.

The project team under the leadership of a project manager define collectively the options of strategies for the project implementation, in which responsibility for each part of the project stage may have already been defined (Storming, see Fig. 3). The outcome of this activity should match the project team strategy in order to create the project charter, which is submitted to a senior manager for approval. At this point, the development of the project team should be aimed towards a termination of the Storming phase with a subsequent transition to the Norming phase (see Fig. 3). [2, 5, 6, 11]

- rules for the project work are

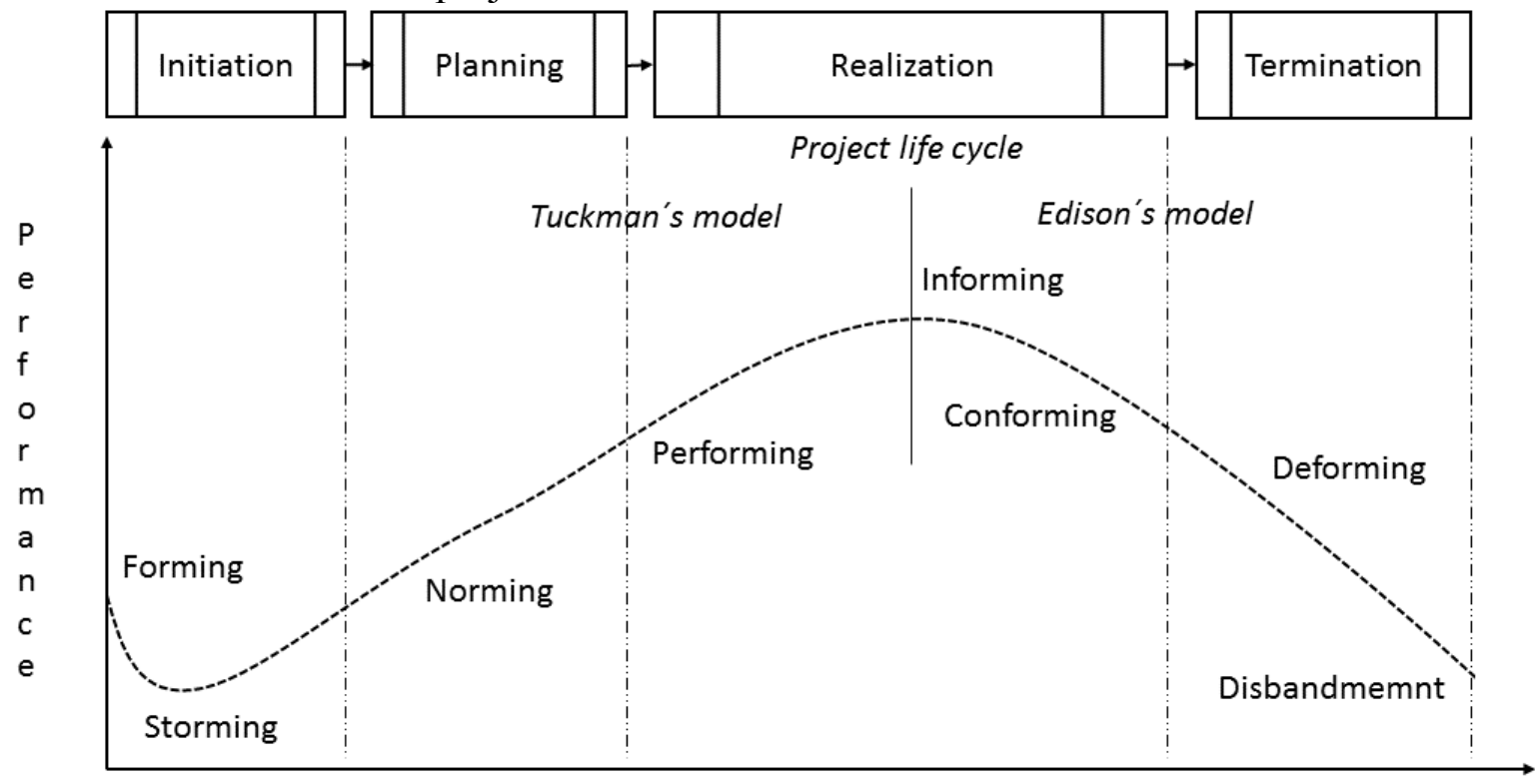

\section{Time}

Figure 3: Model of project team development $\mathrm{x}$ project life cycle

Development of the project team continues in the planning stage. In this stage, the increase of the project team performance is expected towards the point of Performing. Plan creation by a project team is the creation of a detailed procedure to achieve set goals while complying with the defined quality criteria of the final product of the project. The project team, headed by a project manager, determines the sub-criteria of the quality of the product produced during the project and creates subprocesses of project implementation to meet the agreed implementation strategies. The project manager in this phase also focuses on the planning of project management (plan of project management, communication plan, reporting etc.) 
After approval of the project plan, the project implementation stage is started, which assumes completion of the Norming stage in the team development and the initiation of the phase "Performing for successful project implementation (achievement of project objectives)".

Development of the project team, from its establishment until its dissolution by a project manager, during its life cycle, is shown in Figure 3. It puts together the Bruce Tuckman model (Forming, Storming, Norming, Performing) and Tom Edisonan model (Informing, Conforming, Deforming), which illustrates a downward phase of the team development $[2,5,9,11]$. This illustration is valid for so called short-term projects lasting up to one year.

Experience of project managers in the Czech Republic dealing with projects lasting longer than one year (long-term projects) show that it is necessary to take into consideration the significant decline in performance in the middle of their implementation phase, which may be accompanied by a number of undesirable phenomena that threaten the success of a project such as: loss of solidarity with the project and with a project team as well. This effect in the development of the project team is shown in Figure 4. Speaking of the above models, Tuckman and Edison models are related to each other and again, Tuckman's and Edison's models.

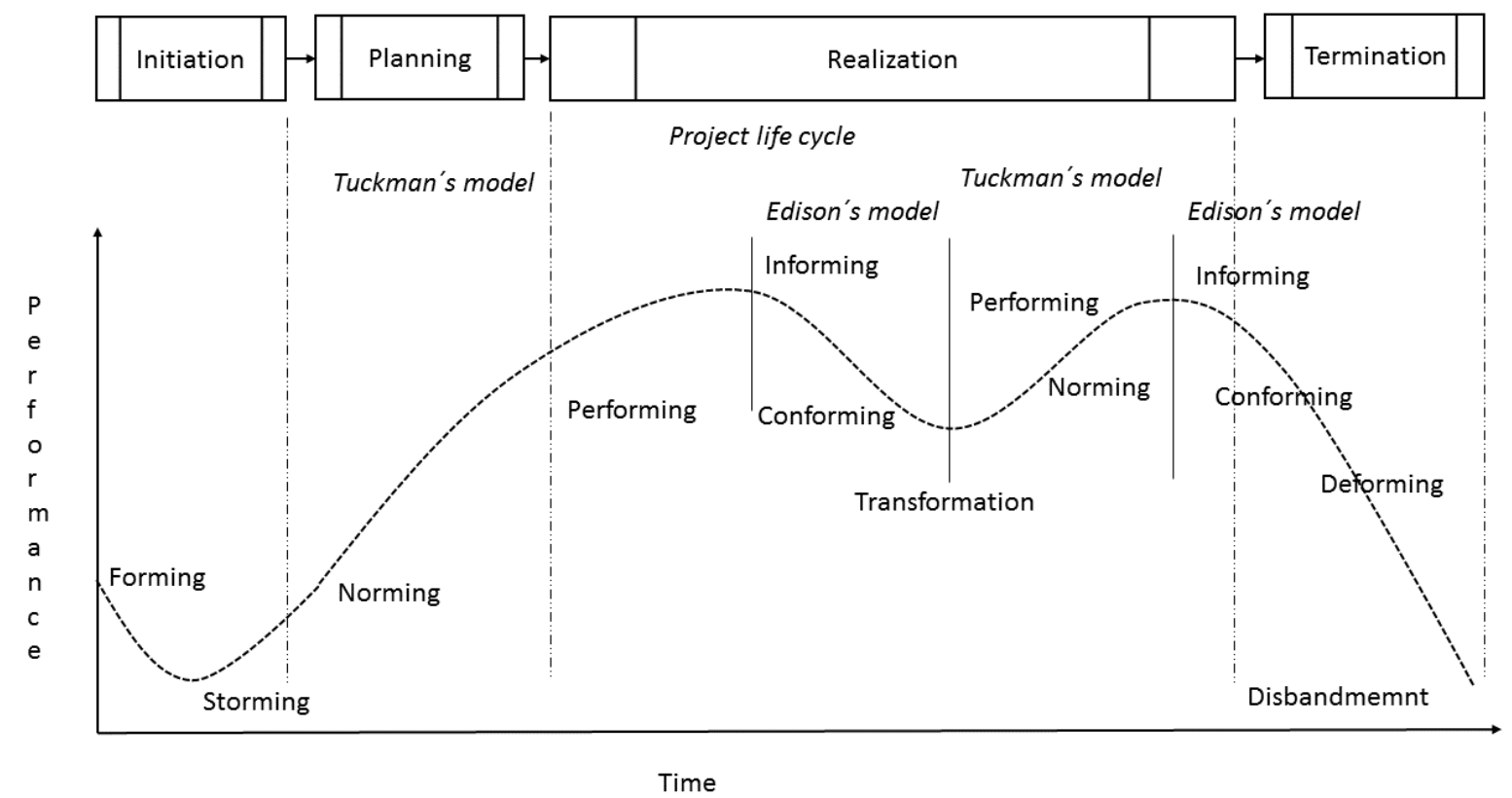
projects

Figure 4: Model of project team development $x$ project life cycle for long-term

\subsection{Success factors of a project management team}

Success of a project management team is primarily influenced not only by the timely selection of a project manager in the initial phase of the project, but primarily by selecting a suitable person who has professional skills, methodological and procedural skills, social and communication skills, the ability to integrate and selfmanage, and therefore has potential and is able lead people. A good, proven manager may still not be automatically a good leader.
The selected manager-leader should then be able to choose the members of the project team who have not only professional skills to ensure the realization of the project objectives, but also are able to work well in a team, or are at least qualified for the work. At the same time, the selected managerleader should be able to withstand external pressures from people who have any inclination toward clientelism, nepotism or other types of corruption. In his/her team, the selected manager-leader should be able to build proper interpersonal relationships, 
an open working atmosphere allowing a high degree of constructive criticism of the results of the work, and respect to otherness, all being beneficial to fulfilling the team roles. Finally, he/she should identify and provide the conditions for quality performance of the project team.

The ability of the project manager to create a functioning internal communication network is already in the Forming phase and the ability of team members to exploit it actively is one of the most important guarantees of a successful project management team.

Without

presentation and argumentation skills, rigorous logic, language skills, decisiveness and the ability to delegate, a project manager would likely not be able to even imagine the project or to define a strategy for the project implementation in the Storming phase.

Project management is based on the assumption that the composition of a project team throughout the project life cycle varies according to the needs of human resources for the implementation of activities in the different phases of the project. There is an important principle the project management team has to take into account: with each change of a team member, the degree of cohesion of the team, interpersonal relations and created an internal communications network might be changed.

The factors affecting a successful project management team include a manager's ability to implement all the key phases of the project life cycle, and lead all individual members of the project team towards a whole in which each part has its justification. It also helps in meeting the project objectives and adherence to timetable and budget.

The ability to work with changes to a project, including the aforementioned decline in the performance of a project team, supposes the following: to make quick decisions and solve flexibly problems such as organization in the middle of a long-term project of a joint meeting of project teams, sponsors of the project, program and portfolio managers (representatives of a steering committee) to remember the expected benefits, the project objectives and thus increase involvement and results orientation of the project (the final product and the goal of the project) and of project team members.

\section{Project management drawbacks in the public sector, and their direct and indirect impacts on goal achievement and satisfaction with the work of the project team}

The effort of the public sector to use the principles and practices of project management for the management and implementation of internal projects does not always lead to the success expected. In addition, a number of public administration bodies have not established a project office. On the other hand, even those entities that have established a project office face many drawbacks. Among the major shortcomings it is possible to include the non-functional office integration in the organizational structure, consisting primarily of nondelegating the appropriate authority to be able to decide, the reluctance to create or use flexible functional communication channels for the project team needs, or incapability to determine personal responsibility for tasks and activities in the case of employees' synergy of different organizational factors in one project.

Data analysis projects implemented in public administration (internal projects) and the authors' experience confirmed that the establishment of the project team is made at the beginning of the initiation phase, which means that the development of a project team is launched at the right time, but the project manager is not given adequate competences. He or she does not choose the project members. The project members are assigned by line managers from various organizational units, usually according to one criterion: the one who will 
be missed as little as possible. This process can have unpropitious consequences, not only for the project management team, but also for its ability to implement the project. Not only will people without the knowledge required to create the final product of the project become part of a project team, but some of them are fully exploited by line managers and do not have the necessary availability for the project.

The project team is usually larger than is actually needed. Besides the implementers of activities, it includes many members who are not directly involved in the performance. Many members of the research team in the project team act as socalled opponents and are focused on the control of a project manager, and whether the interests, linear processes of their workplaces, as well as the requirements for the implementation of these linear processes, are fulfilled.

In this case the project beginning is inflexible, and creating a functional communication structure is almost impossible due to the large number of project team members. It is possible to have a deficiency of information as well as an excess. On one hand, information is not transmitted at the necessary speed, volume and quality. On the other hand, necessary filtration of information does not occur, and clearly identified communication links are not determined. Consequently, team members are overloaded.

Experience from projects in the public sector has shown that unlike assumptions in relation to the composition of the project team (project manager and his subordinate research team), the team composition throughout the project life cycle is not generally changed. The changes usually occur at the level of project teams or team subprojects that are generated for a prescribed period during a project implementation.

The project is not often managed according to the individual phases of the project life cycle. Frequently, planning and termination phases are omitted. Under the slogan of reducing administration, project managers try to avoid the planning stage of the project life cycle and are only guided by the milestones set out in defining the project. After beginning a project, they very quickly start its implementation. Mostly by themselves or with a few team members they set the desired outputs, sub-criteria of quality of products produced by the project, the processes and sub-processes of implementation for fulfilling the agreed strategy. Other members of the research team are involved in creating enumerated elements only from a position of control of their own work. Therefore there is not a necessary endorsement strategy of the project implementation, which affects the identification of team members with activities and affects the quality of their performance and rate of solidarity with the team. Members of the project team in this situation are not interested in achieving the project objectives but in achieving their own interests (e.g. project team members do not defend the interests of the project - the project objectives, but the interests of their own workplaces). In the termination phase, the evaluation of the project is not implemented or is implemented only formally. Sharing experiences and learning from mistakes does not then influence the quality of work on subsequent projects.

What impacts do these deficiencies have on meeting the project objectives and the satisfaction of the project team members?

Project team does not reach a point of Performing. Its greatest achievement may only be the achievement of a Norming phase and maintaining this condition.

Project team for a large number of members does not work as a team, relations among team members are not created, all team roles ensuring the natural functioning of the team are not included.

Communication between the project manager and research team are broken, which results in the disruption of the 
timetable for project implementation.

Motivation and involvement of the research team with respect to the project objectives project falls.

Work in the project team is perceived by its members as an unwanted burden and ways to avoid the burden are sought.

Outcomes of the project are only generated by $20 \%$ of the team members (Pareto's rule 80/20), others merely do not work and the undesirable consequence of the "stowaway" occurs, which has retroactive effect on team morale.

The project manager does not work as a project manager, only as administrator and coordinator of the project.

The likelihood of successful achievement of project objectives is low (especially in terms of time and costs).

\section{Approaches to mitigate negative effects}

For public sector organizations, it is important to note that the implementation of internal projects cannot manage and implement projects in the main organizational structure with a high degree of hierarchy without interference into internal communication of an organization and without defining the authority and delegation of responsibility.

When working on a project, it is better to replace management by leadership, to prioritize quality of activities over quantity, or formal meeting deadlines and other parameters, to pay attention to the careful selection of a project manager and, subsequently, of the project team, and to focus on the project evaluation.

In project management it is necessary to respect the important principle that every project has its own specifics, each project team is a unique community. Although it is not possible to give the guaranteed procedures, it is possible to offer the best use of project management tools and compliance with the principles and rules. The addressed project managers in the previously mentioned research reported the following factors leading to successful project management:

- experience, practice;

- competent and motivated project team and a good project manager;

- strong and working project sponsor, support of the organization management;

- established rules, processes, roles, clarifying the responsibilities between the project and line management;

- open communication, communication on a personal level, telling the truth, regular team meetings;

- unambiguous determination of the assignment;

- leading the concerned parties, especially active communication with the customer project;

- work with risks;

Consistency, accent on quality, for example recording of important decisions and agreements and so on.

\section{Conclusion}

In public administration, apart from short-term projects, the long-term projects are implemented. The management and leadership of team projects must be prepared to cope with a decline in a team's performance in the implementation phase of the project. The authors focused on factors that are associated with human factors. Successful implementation of project management in the public administration sector was significantly associated with people, a change in their thinking and approach to work. Public administration and project-functioning organizations with completely different cultures that promote different values as well as different approaches to the job, or views on demandingness and performance assessment, give completely different possibilities on how to react to changes. Project team members are knowledge workers, who prefer univocal leading to management and are motivated by modern methods, such as coaching. On the contrary, 
they are demotivated by conventional external control. methods of management with increased

\section{References}

[1] DAIGELER, Thomas. Vedení lidi v kostce. Praha: Grada Publishing, a.s. 2008, 105 s. ISBN 978-80-247-2158-3

[2] DOLEŽAL, J., MÁCHAL, P., LACKO, B. a kolektiv. Projektový management podle IMPA. 2., aktual. a dopl. vyd. Praha: Grada Publishing, a.s., 2012, 528 s. ISBN 978-80247-4275-5.

[3] NEKVAPILOVÁ, Ivana. Využití argumentačních postupů v práci manažera projektu. In: Sbornik konference PRONT 05, Acta EVIDA № 41, Plzeň: Sdružení EVIDA Plzeň, 2005, s. 143 - 148, ISBN 80-86596-65-6.

[4] PITAŠ, J. et al. Národní standard kompetencí projektového řizení verze 3.2 - National standard competences of project management version 3.2. 3. vyd. rozšířené Brno: Společnost pro projektové řízení o.s. ve spolupráci s VÚT Brno, 2010, 335 s. ISBN 97880-260-2325-8.

[5] PITAŠ, Jaromír; KALVODA, Vít; HRŮZA, Petr. Stakeholder Management in Project Environments. In: 17th International Science Academy 2015. Paříž, Francie: World Academy of Science, Engineering and Technology FZE, 2015, p. 4021-4025. ISSN 1307-6892.

[6] Project management Institute. A Guide To The Project Management Body Of Knowledge (PMBOK ${ }^{\circledR}$ Guide). $5^{\text {th }}$ edition. Pennsylvania: Project management Institute, Inc., 2013, 589 p. ISNB 978-1-935589-67-9.

[7] Projektové ř́zeni 2015 - Zpráva o výsledcích šetření. http://cspr.cz/wpcontent/uploads/2016/01/PROJEKTOVÉ-ŘÍZENÍ-V-ČR-2015-vysledky_final.pdf. Cit. 22. 3. 2016.

[8] Projektové ř́zeni 2012 - Zpráva o výsledcich šetření. http://cspr.cz/wpcontent/uploads/2015/04/Zprava_pruzkum_PM_2012_SPR_web.pdf. Cit. 22. 3. 2016.

[9] SVOZILOVÁ, A. Projektový management. 2., vyd. aktual. a dopl. vyd. Praha: Grada Publishing a.s., 2011, 392 s. ISBN 978-80-247-3611-2.

[10] TURECKIOVÁ, Michaela. Klíč $k$ účinnému vedení. Odemkněte potenciál svých spolupracovníkù. Praha: Grada Publishing, a.s., 2007. ISBN 978-80-247-6207-4

[11] Danielseet's management diary. Critical Team Development and Intervention Tips for Project Managers.https://danielseet.wordpress.com/2008/12/23/critical-teamdevelopment-and-intervention-tips-for-project-managers/. Cit. 16. 3. 2016. 